\title{
SHOULD FEMALE STUDENTS DEVELOP A TRANSFORMATIONAL LEADERSHIP IN THE FUTURE?
}

\author{
Sonia Agut, Francisco Lozano, Rosana Peris \\ Dept. of Psychology. Universitat Jaume I (SPAIN)
}

\begin{abstract}
Women have incorporated into the labour market and also at all levels of the educational system in a massive way, particularly since the second half of the 20th century. However, from a transversal perspective, the situation of women is not similar to that of men. The reality is that women meet many barriers to fully develop a career that allows them to occupy positions of high responsibility. After being subject to stricter standards for promotion, they are still underrepresented in top management positions, because there is a so-called glass ceiling that prevents them to get up there. This leads them to remain stagnant in middle responsibility roles, which are below their potential. Moreover, when women climb to upper management jobs, they still face another form of discrimination, because they are often appointed to positions that are more precarious and associated with a higher risk of failure than those occupied by men. Gender stereotypes and the perceived incongruity between the female role and leadership roles (i.e., think manager-think male) are the main mechanisms that help us to understand these phenomena. However, new demands on organizations are producing changes in the definition of what a good leader. It seems that nowadays a good leader should be more focused on people, be less agentic and more communal. Order and control are valued less, while know to how to communicate, listen, teach, and encourage are appreciated much more. Those elements are closer to the transformational leadership qualities, that the qualities of the traditional leader. Particularly, transformational leader enhances the motivation, morale, and performance of followers through a variety of mechanisms. Transformational leadership encompasses four dimensions, that is, individualized consideration, intellectual stimulation, inspirational motivation, and idealized Influence. It is considered in general androgynous (i.e., masculine and feminine) or even slightly feminine. Therefore, despite the female university students finish their degrees and post degrees with excellent grades, even better than their male peers, when they are incorporated into the labour market and wish to promote to management positions, they should bet on this kind of leadership. In fact, empirical evidence suggests that female leaders are more transformational than male leaders. On the basis of a review of the most recent studies on the topic, the aim of this paper is to analyse the implications of transformational leadership for current female university students who may be the future leaders in the medium to long term.
\end{abstract}

Keywords: Transformational leadership, gender stereotypes, female university students.

\section{INTRODUCTION}

The increasing incorporation of women into the labour world began as a result of World War I and accelerated in the later decades of the twentieth century. Gradually women were introduced in professions that were previously reserved for men [1], as it were assumed to be hazardous or requiring certain physical skills that they seemed to lack. Since then, more and more have a job or wish to have one and, therefore, have greater weight in the overall economic activity $[2,3]$. There has also been an important increase in the educational level of the population in general. According to United Nations data referred to 2015, the past two decades have witnessed notable progress in participation in education. Enrolment of children in primary education is at present nearly universal. The gender gap has narrowed, and in some regions girls tend to perform better in school than boys and progress in an appropriate manner. Although gender disparities in access to secondary education have been decreased, they remain wider and more prevalent than at the primary level. Gender disparities are even broader at the tertiary level.

Female participation in tertiary education overall has increased globally and currently surpasses male participation in almost all developed countries and in half of developing countries. However, women are clearly underrepresented in fields related to science, engineering, manufacturing, and construction. Women are also underrepresented in the more advanced degree programmes, especially in science-related fields, resulting in fewer women than men in research [4]. 
In Spain, in the 25 years from 1982 to 2007 , women have progressively joint all levels of education. The number of women with secondary education has increased by $200 \%$, but even more notable has been the increase in women with university education [5]. More and more women with higher levels of qualification work or plan to do so in jobs that previously had vetted and therefore have a more significant weight at workplace. However, from a transversal perspective, women situation is not analogous to men position. For many women, significant gains in education have not translated into better labour market outcomes. This is reflected in the difficulty of many women to fully develop a professional career that allows them gain positions of high responsibility.

\section{WOMEN AND LEADERSHIP}

The inequality of women in the labour world is very well reflected in the difficulty of many of them, in comparison to men, to pursue a career that would lead them to positions of responsibility in government or private companies. In fact, women rarely reach the top, and get stuck in jobs that are below their potential. Moreover, the scarce number of women that leaves behind low and middle management jobs and reaches top management positions, still copes with another form of discrimination because they are often appointed to positions that are more associated with greater chance of failure than those occupied by men.

\subsection{Low female participation in responsibility jobs}

This invisibility in leadership and decision-making positions has led to different authors [6, 7, 8, and 9] as well as government agencies [10], show and denounce the existence of so-called glass ceiling. The first use of this term is documented in 1984, by the editor of a magazine, Gay Bryant. It was popularized in 1986 when the glass ceiling was the central theme of an article in Wall Street Journal [11]. This term is a metaphor that refers to the "invisible" barriers that women face in most organizations when trying to access management positions [12]. These barriers prevent many women with personal and professional capacity to positions in management environments and promoted within them [13].

The most important barriers include the occupational segregation and employment discrimination. Women also seem to have fewer opportunities to develop their career, because even without children are considered potential mothers. To this we must add that, generally, women are usually found excluded from informal social networks of power and are less prepared for games and strategies of company policies, which are precisely those that facilitate the access to management positions [14 and 15]. The absence of a consolidated labour policy favouring conciliation of work, family, and personal life is also a factor to consider. The belief that women do not manage or lead as well as men has also been used to justify why they do not access to the highest levels of the occupational hierarchy.

There is an especially relevant factor in understanding why the glass ceiling appears. We refer to the influence of gender stereotypes [16]. In fact, the glass ceiling is actually a result of gender stereotypes and the expectations they generate on how women behave and how should behave in leadership positions [15]. Gender stereotypes are a set of socially shared beliefs about the characteristics and habitual behaviours of men and women [17], applied indiscriminately to all members of the group. Stereotypes encompass a descriptive component (i.e., how the members of the group are and behave) and a prescriptive component (i.e., how women/men should be and behave).

\subsection{Women as managers in crisis companies: the glass cliff metaphor}

Moreover, the scarce number of women that leaves behind low and middle management jobs and reaches top management positions, still copes with another form of discrimination, the so-called glass cliff [18]. It alludes to the fact that women are often appointed to positions that are more unstable, and associated with greater chance of failure than those occupied by men [18, 19, and 20]. In the recent years, empirical evidence demonstrates and replicates it in several contexts as well as in different countries [19]. Individuals prefer to select women to lead under struggling conditions but like better men to lead in more thriving situations $[19,20]$.

The literature analyses the processes underlying glass cliff, and the explanation that has received the most attention from researchers is gender stereotypes [21]. Women are considered better crisis managers, since it is assumed that they have the communal attributes which seems to be particularly useful in times of crisis or risk rather than the agentic ones. In addition, these qualities are closer to 
the notion of transformational leader [22] that we explain further in the next section. The ideal managers of unsuccessful companies are associated with the female stereotype (e.g., understanding, intuitive, tactful) rather than the characteristics that are stereotypically male (e.g., decisive, assertive) [23]. Thus, in these contexts, people are more likely to make the alternative think crisis-think female association [20], rather than the association of manager with masculinity. This suggests that there is no single prototype of a good leader across all situations [24], rather is context-dependent [20]; hence when the context changes, the stereotypical characteristics of women and the requirements of leader roles may be perceived more congruent [25].

\section{TRANSFORMATIONAL LEADERSHIP}

In 1985 Bass [26] proposed two types of leadership: transactional and transformational leadership. Transactional leadership is based on the exchange between the leader and his or her followers. The leader provides objective rewards (e.g., money or promotion) to the followers or subordinates, while they do their tasks and provide support to her or him. The leadership based on exchange, when is well used, obtains positive effects and can explain certain changes in the followers as well as the organization. This has been the predominant way of conceiving the leadership within the Psychology until the middle of the 1980s. However, according to Bass, transactional leadership is not enough to explain the important effects that certain leaders produce on his or her followers.

To do this, it is necessary to incorporate another type of leadership, what is called transformational leadership. Transformational leaders are able to inspire his or her followers to go beyond expectations through various strategies: a) increase the level of understanding of the followers about the work to be carried out; b) get the followers to transcend their own interest in the interest of the group; c) change the importance of the hierarchy of needs of the followers, in such a way that the higher needs such as self-actualization, acquire more importance than the more basic, such as material benefits or safety needs [27]. In contrast to transformational and transactional leadership, another style is examined, what is called laissez-faire leadership, which is characterized by a general failure to take responsibility for managing.

As Craig summarizes [28], according to Bass and colleagues [26, 29, 30], transformational leadership is characterized by the following (Table 1).

Table 1: Dimensions of transformational leadership.

Idealized influence

Transformational leaders become role models for followers who admire, respect, and trust them. They out followers' needs above their own, and their behaviour is consistent with the values and principles of the group.

\section{Inspirational motivation}

Transformational leaders motive by providing meaning and challenge to the tasks of followers. They arouse team spirit, are enthusiastic and optimistic, and help followers develop desirable visions for the future.

\section{Intellectual stimulation}

Transformational leaders stimulate innovation and creativity. They do so by encouraging followers to question assumptions, reframe situations, and approach old problems from new perspectives. Transforming leaders do not criticize errors but instead ask solutions from followers.

\section{Individualized consideration}

Transformational leaders act as coaches or mentors who look after personal development. They provide learning opportunities and a supportive climate for growth. Their coaching and mentoring are tailored to the individual needs and aspirations of each follower.

According to Craig [28], a list of products of transformational leadership [31] is found in Table 2. 
Table 2: Products of transformational leadership.

\begin{tabular}{|c|}
\hline Transformational leaders \\
\hline Raise awareness of moral standards \\
\hline Highlight important priorities \\
\hline Increase followers' need for achievement \\
\hline Foster higher moral maturity in followers \\
\hline Create an ethical climate (shared values, high ethical standards) \\
\hline Encourage followers to go beyond self-interests to the common good \\
\hline Promote cooperation and harmony \\
\hline Use authentic, consistent means \\
\hline Use persuasive appeals based on reason \\
\hline Provide individual coaching and mentoring \\
\hline Appeal to the ideals of followers \\
\hline Allow followers freedom of choice \\
\hline
\end{tabular}

\section{TRANSFORMATIONAL LEADERSHIP AND GENDER}

Much of the interest in women as leaders has focused on whether they lead differently than men. One of the most interesting differences has its origin in the diverse conceptions of power held by women and men. Studies show that women perceive leadership as a tool for solving problems and empowering group members (instrumental power), while for men it would be an opportunity to exercise the authority (final power) given by the position they hold [32]. They also differ in assessing performance, with women focusing on strengthening social interaction and converting their goals into "shared goals" aimed at achieving the common good [33]. For their part, men reward, punish, or distinguish, depending on performance [34].

Also personality has been introduced in the relationships between gender and transformational leadership [35]. The results of this study indicate that gender and personality have impact in leadership behaviour. Women regard themselves as more enabling and rewarding, and men see themselves as more challenging. Subordinates regard female as intuitive and judging types as more transformational than men with similar preferences. Challenging behaviour is clearly emphasized in the leadership behaviour of perceiving male leaders.

A meta-analysis [36] examined different studies comparing men's and women's transformational, transactional, and laissez-faire leadership. Results reveal small sex differences. Women are generally more transformational than men and also more transactional in terms of providing rewards for satisfactory performance. Women's transformational leadership differ most from men's in individualized consideration, that is focus on developing and mentoring followers and attending to their individual needs. On the contrary, men, compared to women, show more transactional leadership by emphasizing followers' mistakes and failures and waiting until problems become severe before intervening. Men are also more likely than women to manifest laissez-faire leadership [37].

Moreover, these findings have implications for female advantage. As Eagly and colleagues reviewed, transformational style and the component of transactional style that implies providing rewards are correlated with effectiveness in contemporary organizational contexts. On the contrary, managers' reliance on the more negative, punishing aspect of transactional leadership is only weakly associated with effectiveness. The transactional component involving delaying action until problems become severe and the laissez-faire style are negatively associated with effectiveness. Thus, the styles favoured by women relate positively to effectiveness, are the styles favoured by men either do not nor do so only weakly [37]. Therefore, in the opinion of Vinkenburg [38] those women who seek to break the barriers and hold top management positions would do well in developing transformational leadership. 
However, we understand that it is necessary to carry out further research before supporting this recommendation, as it seems to present some weaknesses that would prevent its effectiveness. An important weakness consists in the own nature of the leadership transformational, as it is supposed that has a character instrumental when is of nature end. To this respect, we must not forget that Baas and Avolio conceptualized leadership transformational as linked to a state of personal development, being necessary to be at the level of self- actualization of the Maslow hierarchy in order to have the maturity that requires this leadership.

Moreover, if people are unware of the differences in female and male styles or the effectiveness associated with the different styles, or if they evaluate the same style less positively when enacted by women than men, any female advantage would be undermined [37]. In this sense, Ayman and colleagues [39] found that the relationship between a leader's self-report on transformational leadership and their subordinates' evaluation of their performance is significantly less positive for female leaders with male subordinates than for female leaders with female subordinates. The male and female subordinates of male leaders rated their performance as equally effective, regardless of their levels of transformational leadership. These subtleties of transformational leadership thus can complicate women's path to high positions [37].

\section{CONCLUSIONS}

On the basis of a review of the most recent studies on women and leadership, the aim of this paper was to analyse the implications of transformational leadership for current female university students who may be the future leaders in the medium to long term. We have noticed that despite women have incorporated into the labour market and also at all levels of the educational system their situation is not similar to that of men.

Women meet many barriers to fully develop a career that allows them to occupy positions of high responsibility. After being subject to stricter standards for promotion, they are still underrepresented in top management positions, because there is a so-called glass ceiling that prevents them to get up there. This leads them to remain stagnant in middle responsibility roles, which are below their potential [12]. The most important barriers include the occupational segregation and employment discrimination. Women also seem to have fewer opportunities to develop their career, because even without children are considered potential mothers. In addition, women are usually found excluded from informal social networks of power and are less prepared for games and strategies of company policies, which are precisely those that facilitate the access to management positions [14, 15]. The absence of a consolidated labour policy favouring conciliation of work, family, and personal life is also a factor to consider. The belief that women do not manage or lead as well as men has also been used to justify why they do not access to the highest levels of the occupational hierarchy. However, there is an especially relevant factor in understanding why the glass ceiling appears. We refer to the influence of gender stereotypes [16]. In fact, the glass ceiling is actually a result of gender stereotypes and the expectations they generate on how women behave and how should behave in leadership positions [15].

Moreover, when women climb to upper management jobs, they still face another form of discrimination, because they are often appointed to positions that are more unstable, and associated with greater chance of failure than those occupied by men (glass cliff) $[18,19,20]$. In the recent years, empirical evidence demonstrates and replicates it in several contexts as well as in different countries [19]. Individuals prefer to select women to lead under struggling conditions but like better men to lead in more thriving situations $[19,20]$. The literature analyses the processes underlying glass cliff, and the explanation that has received the most attention from researchers is gender stereotypes [21]. Women are considered better crisis managers, since it is assumed that they have the communal attributes which seems to be particularly useful in times of crisis or risk rather than the agentic ones.

These qualities are closer to the notion of transformational leader [22]. As well, new demands on organizations are producing changes in the definition of what a good leader. It seems that nowadays a good leader should be more focused on people, be less agentic and more communal. Order and control are valued less, while know to how to communicate, listen, teach, and encourage are appreciated much more. Those elements are also closer to the transformational leadership qualities, that the qualities of the traditional leader $[22,36]$. Particularly, transformational leader enhances the motivation, morale, and performance of followers through a variety of mechanisms. Transformational leadership encompasses four dimensions, that is, individualized consideration, intellectual stimulation, inspirational motivation, and idealized Influence [26, 29, and 30]. Transformational leaders are able to 
inspire his or her followers to go beyond expectations through various strategies: a) increase the level of understanding of the followers about the work to be carried out; b) get the followers to transcend their own interest in the interest of the group; c) change the importance of the hierarchy of needs of the followers, in such a way that the higher needs such as self-actualization, acquire more importance than the more basic, such as material benefits or safety needs [27]. It is considered in general androgynous (i.e., masculine and feminine) or even slightly feminine.

Therefore, despite the female university students finish their degrees and post degrees with excellent grades, even better than their male peers, when they are incorporated into the labour market and wish to promote to management positions, perhaps they should bet on this kind of leadership. In fact, empirical evidence suggests that women were generally more transformational than men and also more transactional in terms of providing rewards for satisfactory performance. In particular, women's transformational leadership differed most from men's in individualized consideration, that is focus on developing and mentoring followers and attending to their individual needs. Moreover, these findings have implications for female advantage. As Eagly and colleagues reviewed, transformational style and the component of transactional style that implies providing rewards were correlated with effectiveness in contemporary organizational contexts. However, empirical evidence [39] suggests that the relationship between a leader's self-report on transformational leadership and their subordinates' evaluation of their performance is significantly less positive for female leaders with male subordinates than for female leaders with female subordinates. The male and female subordinates of male leaders rate their performance as equally effective, regardless of their levels of transformational leadership. These subtleties of transformational leadership thus can make difficult women's path to high positions [37].

Thus, unfortunately transformational leadership does not constitutes the panacea for female university students in order to receive equal treatment in the labour market, in comparison with men, and thus achieve positions of responsibility and power as their males peers. It could be an advantageous leadership style for women, but this leadership alone does not guarantee that the women can access to positions of leadership and be recognized as efficient leaders.

\section{REFERENCES}

[1] L. Wirth, "Romper el techo de cristal. Las mujeres en puestos de dirección", Colección Informes OIT, no. 58, 2002.

[2] M. Davidson, "Women and employment". In P. Warr (dir.): Psychology at work. Penguin Book Sheffield, 1991.

[3] OCDE. "La integración de la mujer en la economía", Informes OCDE. Ministerio de Trabajo y Seguridad Social. Madrid.1986.

[4] United Nations. "The World's Women 2015 Trends and Statistics", United Nations Statistics Division, 2015. Retrieved from: http://unstats.un.org/unsd/gender/chapter3/chapter3.html

[5] Instituto de la Mujer. Estadísticas. Empleo, 2010. Retrieved from: http://www.migualdad.es/mujer/mujeres/cifras/empleo/index.html

[6] R. H. Chernesky, "Examining the glass ceiling: Gender influences on promotions decisions", Administration in Social Work, no. 27, pp. 13-18, 2003.

[7] G. N. Powell, "Reflections on the ceiling glass. Recent trend and future prospects". In G. N. Powell (ed.): Handbook of gender and work. Sage Publications. Thousand Oaks, CA, 1999.

[8] M. Reid, W: Miller, W. \& B. Kerr, "Sex-Based Glass Ceilings in U.S. State-Level Bureaucracies, 1987-1997", Administration \& Society, vol. 36, no. 4, pp. 377-405, 2004.

[9] A. E. M. van Vianen, \& A. H. Fischer, "Illuminating the glass ceiling: The role of organizational culture preferences", Journal of Occupational and Organizational Psychology, no. 75, pp. 315337, 2002.

[10] ILO, "Romper el techo de cristal. Las mujeres en puestos de dirección Actualización 2004". Geneva: International Labour Organization. Retrieved from:

http://www.ilo.org/dyn/gender/docs/RES/292/F61986410/Romper\%20el\%20techo\%20de\%20cri stal.pdf 
[11] M. Barreto, M. Ryan, \& M. T. Schmitt, "Introduction: Is the glass ceiling still relevant on the $21^{\text {st }}$ century?" In The glass ceiling in the 21st century: Understanding barriers to gender inequality American Psychological Association. Washington, DC., 2009.

[12] A. M. Morrison, R. P. White, \& E. van Velsor, "Breaking the glass ceiling", Addison-Wesley. Readin, 1987.

[13] M. Sarrió, E. Barberá, A. Ramos, \& C. Candela, "El techo de cristal en la promoción profesional de las mujeres", Revista de Psicología Social, vol. 17, no. 2, pp. 167-182, 2002.

[14] N. Chinchilla, \& C. León, "La ambición femenina. Cómo re-conciliar trabajo y familia”, Aguilar. Madrid, 2004.

[15] I. Cuadrado, M. Navas, \& F. Molero, "Mujeres y liderazgo. Claves psicosociales del Techo de Cristal", Sanz y Torres. Madrid, 2006.

[16] M. E. Heilman, "Description and prescription: How gender stereotypes prevent women's ascent up the organizational ladder", Journal of Social Issues, no. 57, pp. 657-674, 2001

[17] S. Worchel, J. Cooper, G. R. Goethals, \& J. M. Olson, "Psicología social", Thomsom Madrid, 2003.

[18] M. K. Ryan, \& S. A. Haslam, The glass cliff: Evidence that women are over-represented in precarious leadership positions, British Journal of Management, no. 16, pp. 81-90, 2005.

[19] S. A. Haslam, \& M. K. Ryan, "The road to the glass cliff: Differences in the perceived suitability of men and women for leadership positions in succeeding and failing organizations", Leadership Quarterly, no. 19, pp. 530-546, 2008.

[20] M. K. Ryan, \& S. A. Haslam, "The glass cliff: Exploring the dynamics surrounding women's appointment to precarious leadership positions", Academy of Management Review, no. 32, pp. 549-572, 2007.

[21] S. Bruckmüller, M: K. Ryan, F. Rink, \& S. A. Haslam, "Beyond the Glass Ceiling: The Glass Cliff and Its Lessons for Organizational Policy”, Social Issues and Policy Revie, no. 8, pp. 202-232, 2014.

[22] A. H. Eagly, \& S. Sczesny, S., "Stereotypes about women, men, and leaders: Have times changed?" In M. Barreto, M. Ryan, \& M. T. Schmitt (eds.): The glass ceiling in the 21st century: Understanding barriers to gender inequality, American Psychological Association. Washington, DC, 2009.

[23] M. K. Ryan, S. A. Haslam, M. D. Hersby, and R. Bongiorno, "Think crisis-think female: Glass cliffs and contextual variation in the think manager-think male stereotype", Journal of Applied Psychology, no. 96, pp. 470-484, 2011.

[24] J. C. Turner, \& S. A. Haslam, "Social identity, organizations and leadership". In: M. E. Turner (Ed.), Groups at work: Advances in theory and research (pp. 25-65). Hillsdale, NJ: Erlbaum, 2001.

[25] A. H. Eagly, \& S. J. Karau, "Role congruity theory of prejudice toward female leaders", Psychological Review, n0. 109, pp. 573-598, 2002

[26] B. M. Bass, "Leadership and performance beyond expectations". New York: Free Press, 1985.

[27] F. Molero, "Liderazgo transformacional y carismático". In F. Molero and J. F. Morales (Coords.), Liderazgo: hecho y ficción, Madrid: Alianza Editorial, 2011.

[28] J. E. Craig, "Meeting the Ethical Challenges of Leadership: Casting Light or Shadow $\left(5^{\text {th }}\right.$ edition)", Thousand Oaks: Sage Publications, 2015.

[29] B. M: Bass, \& B.J. Avolio, "Improving organizational effectiveness through transformational leadership", Thousand Oaks, CA: Sage Publications, 1994.

[30] B. M. Bass, B. J. Avolio, D. I. Jung, and Y. Berson, "Predicting unit performance by assessing transformational and transactional leadership", Journal of Applied Psychology Vol. 88, No. 2, pp. 207-218, 2003.

[31] B. M: Bass, "The ethics of transformational leadership". In J. Ciulla (Ed.), Ethics: The heart of leadership (pp. 169-192). Westport, CT: Praeger, 1998. 
[32] H. Fennell, "Walking a fine balance. The life history of a woman principal", Journal of Women in Educational Leadership, vol. 6, no. 2, pp. 93-113, 2008.

[33] J. Rosener, "Ways women lead", Harvard Business Review, no. 68, pp.119-12, 1990.

[34] M. Thompson, "Gender, leadership orientation and effectiveness: Testing the theoretical models of Bolman \& Deal and Quinn”. Sex Roles, vol. 42, no 11/12, pp. 969-992, 2000.

[35] T. Brandt, \& M. Laiho, "Gender and personality in transformational leadership context an examination of leader and subordinate perspectives", Leadership \& Organization Development Journal, vol. 34 no. 1, pp. 44-66, 2013

[36] A.H. Eagly, M.C. Johannesen-Schmidt, \& M.L. Van Engen, "Transformational, transactional, and laissez-faire leadership styles: a meta-analysis comparing women and men", Psychological bulletin, vol. 129 , no. 4, pp. 569-591, 2003.

[37] A. H. Eagly, L. Gartzia, \& L. Carli, "Female Advantage Revisited". In S. Kumra, R. Simpson \& R. Burke (Eds.), Oxford Handbook of Gender in Organizations (pp.153-174). England: Oxford University Press, 2014.

[38] C. J. Vinkenburg, M. L. Engen, A. H. Eagly, \& M. C: Johannesen-Scmidt, "An exploration of stereotypical beliefs about leadership styles: Is transformational leadership a route to women's promotion?", The Leadership Quarterly, no. 22, pp. 10-21, 2011.

[39] R. Ayman, K. Korabik, and S. Morris, "Is Transformational Leadership Always Perceived as Effective? Male Subordinates' Devaluation of Female Transformational Leaders", Journal of Applied Social Psychology, no.39, pp. 852-879, 2009. 